\title{
THE EFFECT OF MINDSET PERSONAL ON BEHAVIOR OF INTERNET ENTREPRENEURSHIP STUDENTS OF UNIVERSITAS PUTRA INDONESIA YPTK PADANG
}

\author{
Muharika Dewi ${ }^{1}$, Erna Susanti ${ }^{2}$, Rina Susanti ${ }^{3}$, Zefri Yenni ${ }^{4}$, dan Eliza $^{5}$ \\ ${ }^{1}$ Program Studi Pendidikan Teknik Informatika, Fakultas Keguruan Ilmu Pengetahuan, \\ ${ }^{2,3}$ Program Studi Sistem Informasi, Fakultas Ilmu Komputer \\ ${ }^{4}$ Program Studi Magister Manajemen, Fakultas Ekonomi dan Bisnis \\ ${ }^{5}$ Program Studi Akuntansi, Fakultas Ekonomi dan Bisnis \\ Jalan Raya Lubuk Begalung, Padang - Sumatera Barat, Indonesia, Telp (0751) 776666 \\ E-mail: mkea2010@gmail.com
}

\begin{abstract}
The importance of understanding mindsets to direct behavior in internet-based entrepreneurship is the effort in bringing entrepreneurial learning processes close to changes in entrepreneurial behavior. This study aims to determine the grouping of students' mind sets in two growth and fixed categories, knowing the description of mind set content and internet entrepreneurial behavior in students, knowing the differences in internet entrepreneurial behavior based on student mindsets, knowing the correlation between mind set and internet entrepreneurial behavior, then know the contribution of mindset to internet entrepreneurial behavior. This research method with a quantitative approach, using a likert scale questionnaire instrument, the sample is students registered at UPI YPTK Padang in 2018/2019 academic year totaling 148 people, sampling from the population is done by purposive sampling technique, data analysis with percentage techniques in describing data, independent test sample $t$ test for different tests, pearson correlation product moment analysis for testing the relationship of variables and the square of $r$ for testing the contribution. The results of the analysis state that $45 \%$ of students with a fixed mind set and 55\% with a growth mind set, students with a growth mind set have better internet entrepreneurial behavior with an average of $86.82 \%$. Hypothesis testing states that there are differences in student internet entrepreneurial behavior based on personal mindsets, there is a fairly strong correlation between mind set with internet entrepreneurial behavior, with a contribution of $20.4 \%$. It is proven that students with growth mindsets have higher behavior in internet entrepreneurial activities, therefore to increase the ability and interest of students in entrepreneurship must start from the approach to the correct mindset about entrepreneurship.
\end{abstract}

Key words: Mindset Growth; Fixed Mindset; Entrepreneur Technology; Entrepreneur Behavior

\section{PENGARUH MINDSET PERSONAL TERHADAP PERILAKU WIRAUSAHA INTERNET MAHASISWA UNIVERSITAS PUTRA INDONESIA 'YPTK’ PADANG}

\begin{abstract}
ABSTRAK. Pentingnya memahami mindset untuk mengarahkan perilaku dalam wirausaha berbasis internet adalah upaya dalam mendekatkan proses pembelajaran wirausaha pada perubahan perilaku wirausaha. Penelitian ini bertujuan untuk mengetahui pengelompokan mindset mahasiswa pada dua kategori growth dan fixed, mengetahui deskripsi konten mind set dan perilaku wirausaha internet dalam diri mahasiwa, mengetahui perbedaan perilaku wirausaha internet berdasarkan mind set mahasiswa, mengetahui korelasi antara mindset dan perilaku wirausaha internet, kemudian mengetahui kontribusi mindset terhadap perilaku wirausaha internet. Metode penelitian ini dengan pendekatan kuantitatif, mengggunakan instrumen angket berskala likert, sampel adalah mahasiswa terdaftar pada UPI YPTK Padang tahun ajaran 2018/2019 yang berjumlah 148 orang, penarikan sampel dari populasi dilakukan dengan teknik purposive sampling, analisis data dengan teknik persentase dalam mendeksripsikan data, uji indipendent sample t-test untuk uji beda, analisis pearson correlation product moment untuk pengujian hubungan variabel dan kuadrat $\mathrm{R}\left(\mathrm{R}^{2}\right)$ untuk pengujian kontribusi. Hasil analisis menyatakan bahwa $45 \%$ mahasiswa dengan mindset fixed dan 55\% dengan growth mindset, mahasiswa dengan growth mindset memiliki perilaku wirausaha internet yang lebih baik dengan rerata $86,82 \%$. Pengujian hipotesis menyatakan bahwa terdapat perbedaan perilaku wirausaha internet mahasiswa berdasarkan mindset personalnya, terdapat korelasi yang cukup kuat antara mindset dengan perilaku wirausaha internet, dengan kontribusi sebesar 20,4\%. Terbukti bahwa mahasiswa dengan growth mindset memiliki perilaku bertindak dalam aktivitas wirausaha internet yang lebih tinggi, karena itu untuk meningkatkan kemampuan dan minat mahasiswa dalam berwirausaha harus dimulai dari pendekatan terhadap mindset yang benar mengenai wirausaha.
\end{abstract}

Kata kunci: Pengaturan Pertumbuhan Pikiran; Pikiran Tetap; Teknologi Wirausaha; Perilaku Wirausaha

\section{INTRODUCTION}

Entrepreneurship is closely related to the formation of one's character. Planting a mindset of success in doing business is the main thing that actually must be done before providing approaches in entrepreneurial learning. The impression that entrepreneurship learning is to win a business opportunity and then become a pedagag is a wrong thinking pattern that has been owned by students in Indonesia. As a result, it is difficult for educators in the entrepreneurship field to give meaning to the importance of entrepreneurship itself. This is not optimal achievement of the objectives of entrepreneurial learning in shaping entrepreneurial behavior for students.

Mindset is beliefs that affect an attacking attitude, a set of beliefs or a way of thinking that determines a person's behavior and outlook, attitude and future. The mental attitude determines the response and meaning 
of the situation (Benny Lo, 2014). Mindset affects the individual's condition to carry out an activity which is then also influenced by one's cognition in carrying out that activity (Gollwitzer, 1990). Entrepreneurial mindset can be divided into deliberative in impartial elaborative actions and more open and implemented (Mathisen \& Arnulf, 2013; McMullen \& Kier, 2016). The deliberative mindset is impartial and open minded. Thus Mindset is a Belief (Trust) or a group of beliefs or ways of thinking that affect the behavior and attitudes of a person who will determine the level of success of his life.

Mindset is a belief that is in a person to make efforts or something that is permanent and cannot be changed (Chrisantiana \& Sembiring, 2017). Self-confidence will make someone continue to learn and try to improve their abilities (Dweck, 2006). Therefore, to be able to form the ability in entrepreneurship, it is important to instill confidence in the right mindset about entrepreneurship.

Mindset is a determining factor for the existence of behavior and actions in carrying out entrepreneurial activities, especially in the 4.0 industrial revolution. The mindset of self-employment in forming a trust that is a driving force is student entrepreneurial activity, having a mind set influences student behavior in entrepreneurship. Carol Dweck, who is famous for the growth mindset theory in 2015, states that mind set is how someone lives their abilities, this is the key to motivation and achievement. The main meaning of this study is that if a student's mindset is changed, achievement will be improved. If related to the study of entrepreneurship, ideally if the student mindset about entrepreneurship is a growth mindset with the theory that basic quality is something that can be developed through business, it will form an entrepreneurial achievement in students. However, if beliefs settle passively and resign themselves to failure will have an impact on the low achievement achieved in entrepreneurship.

The problem of unemployment is a trend that weakens economic development in many countries. It also impedes personal and family welfare, entrepreneurial career development is a solution that is considered practical in overcoming the problem of unemployment. Entrepreneurship studies in recent decades have been the focus of research in most countries (Hindle \& Moroz, 2010; Schildt, 2012; Welter \& Lasch, 2008). In many findings stated that entrepreneurship has a role in alleviating poverty, increasing income and economic growth, job creation (Romer, 1994). The main characteristic of an entrepreneur's excellence is his innovation, creativity in a product or service so that he is able to have an advantage that has more value. Creative thinking patterns that can be formed through habituation in life will have an impact on one's creative actions (Mc.Grath \& Mac.Millan, 2000).
But how can an entrepreneurial career develop if the mindset develops in an entrepreneurial career not formed within students. For that reason, to find out whether entrepreneurial activity can be influenced by the mindset within students, a research is needed to determine the influence of personal mindset on internet technology-based entrepreneurial activities, to know the relationship and contribution of mindset to internet entrepreneurial behavior shown by UPI YPTK Padang students.

\section{METHODS}

The method used in this research is the quantitative method is one of the efforts of scientific inquiry (scientific inquiry) based on the philosophy of logical positivism (logical positivism) which operates with strict rules about logic, truth, laws, and predictions (Watson, in Danim 2002). The focus of quantitative research is identified as a work process that takes place in a concise, limited and sort out problem into a part that can be measured or expressed in numbers. The quantitative approach emphasizes the existence of variables as research objects and these variables must be defined in the form of the operationalization of each variable. Reliability and validity are absolute requirements that must be met in using this approach because these two elements will determine the quality of research results and the ability to replicate and generalize the use of similar research models. Furthermore, quantitative research requires a hypothesis and testing which will then determine the next steps, such as determining the analysis techniques and statistical formulas that will be used. Also, this approach gives more meaning in relation to interpretation of statistical figures rather than linguistic and cultural meanings. The steps of quantitative research are the operationalization of the scientific method by taking into account scientific elements. Quantitative research as a scientific activity begins with a problem, refers to theories, suggests hypotheses, collects data, analyzes data, and makes conclusions. Quantitative research begins with a problem that can be extracted from empirical and theoretical sources, as a preliminary research activity. In order for problems to be found properly they need empirical facts and are accompanied by mastery of the theory obtained from studying various relevant literature. Research is carried out systematically, empirically, and critically about phenomena guided by theories and hypotheses. Research activities begin by identifying problems or issues that are important, actual and interesting. And, the most important is the benefits generated when the problem is examined. Problems can be explored from various empirical or theoretical sources as preliminary research activities (pre-research). In order 
for problems to be found properly empirical facts need to be accompanied by mastery of the theory obtained through the study of various relevant literature. In the next stage, research sees the goal as a problem. Problems that have been found are formulated in a problem statement. In general the formulation of quantitative research problems is arranged in the form of questions. The formulation of the problem is the determination of the factors or aspects related to the scope of the study study.

In practice the factors and aspects related to the study of problems are numerous and complex. Therefore it is necessary to limit only the dominant factors or aspects. Research divides the problem into sub-problems that can be managed in the sense that it is feasible and affordable to study. Each sub-problem is searched for possible specific answers in the form of an appropriate hypothesis. In this case a literature study is needed, namely the activity to study the theories that underlie research. In this activity empirical matters were also examined from previous studies. The research temporarily holds the hypothesis or questions until all data is collected and interpreted. In the next stage, the research is directed to look for data based on the formulation of the problem and the hypothesis stated earlier. In this case a research design is needed which contains the stages of research, research methods, data collection techniques, data sources (populations and samples), and the reasons why using these methods. Before data collection activities are carried out, instrument preparation and testing techniques must be determined which will be used for data collection. The data obtained were then analyzed using statistical techniques. The results of data analysis are findings that have not been given meaning. The meaning of the results of data analysis is done through interpretations that lead to efforts to overcome problems or answer research questions. In this stage the hypothesis is accepted or rejected. Interpretation is made by looking at the relationship between one finding and another. The conclusion is a generalization of the results of interpretation. The conclusions obtained are then created the implications and recommendations as well as suggestions for the utilization of research results. Furthermore, this research was conducted to student representatives from six faculties at Universitas Putra Indonesia YPTK Padang. Samples were taken based on purposive sampling techniques from the population of active college students in the 2018/2019 school year with a sample requirement of 148 students. The instrument used was a Likert scale questionnaire. Pretest measuring a student's mind set is done to group students into a growth mindset or fixed mindset. Then do the comparison of internet entrepreneurial behavior activities carried out by students using independent sample t-test for unpaired samples, then a correlation between mindset and internet entrepreneurial behavior using pearson correlation product moment.

The mindset content content that becomes the valuer variable is 1) Confidence regarding intelligence, talent, and character, 2) Belief in challenges, difficulties and failures, 3) Beliefs about the impact of effort on self-development, 4) Confidence in criticism and input received from others, (Dweck, 2006). Meanwhile, the content of internet entrepreneurial behavior assessment is 1) Strong passion in the products it sells, 2) Understanding the desires of others (Empathy), 3) Ability to convince others with Communication, 4) Honesty, 5) Innovative, 6) Visionary, 7 ) Focus (Muharika \& Mulyani, 2019).

\section{RESULTS AND DISCUSSION}

\section{Student Classification based on Mindset}

Based on the results of data analysis obtained from the Likert scale questionnaire with 20 questions to determine the grouping of students in two categories, namely Growth Mindset (score 100-51) and Fixed Mindset (score 50-0), it can be seen that there are 67 people $(45 \%)$ students who have growth mindset categories and 79 people (55\%) students have fixed mindset categories. Entrepreneurial mindset is the ability to feel, act and mobilize quickly, even in conditions of high uncertainty (Naumann, 2017). Entrepreneurs are always on the lookout for new opportunities, realize the scarce resources they have and can be utilized to benefit, adapt to developments by utilizing existing internal and external networks (Mc. Grath \& Mac.Millan, 2000). The set of entrepreneurial sets is ways of thinking with competitive advantage in uncertainty situations, entrepreneurial mindset is the result of meta-cognitive awareness that forms "the ability to adapt thinking processes to changing contexts and task demands" (Ireland et al., (2001). Shepherd et al., ( 2010) states that the entrepreneurial mindset is the ability to quickly feel, act, and mobilize in response to decisions made under uncertainty to exploit opportunities Baron (2014) emphasizes the uniqueness created by entrepreneurs by the way they "think, reason, make decisions, plan, and set goals, formed by pe experience, knowledge, heuristics and networks. Mindset in students tends to be in the form of growth mindset with excellence in the formation of basic qualities in a person through the efforts made.

\section{Student Mindset based on Growth Mindset and Fixed Mindset Variable Content Variables}

After grouping students according to mindset, a statistical analysis is then performed to determine the percentage of mind set content values in each group of students. The results can be seen in the following Table 1: 
Table 1. Student Content Mindset

\begin{tabular}{lccc}
\hline \multicolumn{1}{c}{ Content } & $\begin{array}{c}\text { Fixed } \\
\text { Mindset }\end{array}$ & $\begin{array}{c}\text { Growth } \\
\text { Mindset }\end{array}$ & Total \\
\hline $\begin{array}{l}\text { Confidence regarding } \\
\text { intelligence, talent, and } \\
\text { character. }\end{array}$ & $42 \%$ & $85 \%$ & $65 \%$ \\
$\begin{array}{l}\text { Confidence in challenges, } \\
\text { difficulties and failures. }\end{array}$ & $4 \%$ & $63 \%$ & $53 \%$ \\
$\begin{array}{l}\text { Confidence regarding the } \\
\text { impact of business on } \\
\text { personal development. }\end{array}$ & $43 \%$ & $84 \%$ & $65 \%$ \\
$\begin{array}{l}\text { Confidence in } \\
\text { criticism and input received } \\
\text { from others. }\end{array}$ & $35 \%$ & $74 \%$ & $58 \%$ \\
\hline
\end{tabular}

Sumber: Data Olahan SPSS V.26

Based on Table 1, it can be explained that the group of students with a fixed mindset has a positive mindset content of success with a percentage below $50 \%$, while the mind set content that is formed on students growth mind set groups has a percentage value above $50 \%$. In the total number of all students, the lowest total mindset content in the beliefs of challenges, difficulties and failures is at the percentage of $53 \%$.

Students with high Intelligence Quotion (IQ) often do not have high achievement, and conversely some students who have low IQ often have high achievement (Hochanadel and Finamore, 2015). Dweck (2013) states that mindset is a belief, and he mentions two types of mindset, namely Growth Mindset and Fixed Mindset. Growth Mindset is the belief that one's basic qualities, like intelligence, are things that can be changed through certain efforts Duckworth and Dweck (Duckworth, 2016) conducted joint research to understand more deeply why some students managed to survive to achieve academic achievement, while others were unable to survive. Through research conducted by Duckworth and Dweck how one's fixed belief about failure is a permanent thing that can hamper academic success, Duckworth concludes that having a growth mindset can develop grit. (Dweck, 1999, 2007, 2010; Duckworth, 2007 in Hochanadel and Finamore, 2015). Carol Dweck began her research on mindset in the field of education to find that if students believe their abilities can change, then they will feel control over their achievements becoming greater and they will focus more on studying a material.

\section{Student Internet Entrepreneurial Behavior}

The results of statistical analysis to find out the percentage of internet entrepreneurial behavior values carried out by students in the group of students with growth mindset and fixed mindset group can be seen in Table 1 below;
Table 2. Student Entrepreneurial Internet Behavior based on Mindset

\begin{tabular}{lcc}
\hline \multicolumn{1}{c}{ Konten } & $\begin{array}{c}\text { Fixed } \\
\text { Mindset }\end{array}$ & $\begin{array}{c}\text { Growth } \\
\text { Mindset }\end{array}$ \\
\hline Passion & $79 \%$ & $87 \%$ \\
Empathy & $66 \%$ & $87 \%$ \\
The ability to convince others & $57 \%$ & $72 \%$ \\
through communication & & \\
Honesty & $79 \%$ & $85 \%$ \\
Inovation & $78 \%$ & $78 \%$ \\
Visionary & $62 \%$ & $88 \%$ \\
Focus & $73 \%$ & $81 \%$ \\
Rerata & $70 \%$ & $83 \%$ \\
\hline
\end{tabular}

Sumber: Data Olahan

The mean value shown in Table 2 above states that the group of students with fixed mind sets has $70 \%$ entrepreneurial behavior while the group of students with growth mindset has a higher average internet entrepreneurial behavior that is $83 \%$. World economic development in the $21^{\text {st }}$ century which is very dynamic requires the existence of creative young people as business people and movers through the use of technology.

Krisianto (2014) states that "the internet is a form of interactive communication and information media. The form of the internet is a network of computers connected throughout the world. The internet is used to send information between computers and other similar devices throughout the world, so that one can access and exchange information quickly ". An internet entrepreneur is someone who involves the great power of the internet to start and develop his business, both with the sale of physical goods or innovative modern services, a successful internet entrepreneur pays attention to several start-ups that involve a mixture of technological developments and traditional ways of doing business (Taylor, 2017). Gerald (2007) revealed that an internet entrepreneur is someone who has a large or small company that explores new business opportunities through the internet network, they make business decisions, create new businesses and employ others through business operations with the help of the internet. Lung (2016) states that internet entrepreneurs are a new generation of entrepreneurs who make efforts to become successful entrepreneurs by establishing an internet-based business. Stevens (2010) states that internet entrepreneurs are those who compete on the internet, by increasing the intensity of time to be able to be "hypercompetitive" in the face of changing nature of the fast-paced environment of doing business. Millman, W. (2009) states that internet entrepreneurs are those who are familiar with the internet technology culture in an effort to develop their business. Matlay (2004) notes that internet entrepreneurship refers to the act of establishing a new company especially in the internet economy. Kollmann 
(2006) states that internet entrepreneurship consists of a new arrangement of companies with innovative business ideas in the internet economy in the 21st Century that is happening right now.

Internet entrepreneurship means the process of establishing a new company with innovative business in the information technology sector. Bennani (2014) suggested that internet entrepreneurs are entrepreneurs who invest in IT-based projects. (Bennani, 2014). Whereas Pourhossein and Omran (2014) state that Internet entrepreneurship is defined as ideas which basically use the Internet to strategically and competitively achieve vision, business goals, and objectives. Entrepreneurs or entrepreneurs use the World Wide Web (WWW) to interact and complete virtual transactions, both with other businesses and consumers / customers. An increasingly rapid development by entering the industrial era 4.0 or later the era of society 5.0 , where, if society 4.0 allows us to access also share information on the internet. Society 5.0 is an era where all technology is part of humanity itself. The internet is not just to share information but to live life. Therefore personally must continue to explore their potential, so that they can face challenges in the future and compete healthily in all fields, especially in creating self-creativity and becoming a figure of innovation in accordance with the times.

\section{Comparison of Student Internet Entrepreneurial Behavior based on Mindset}

Students who have been grouped into two groups namely fixed mindset and growth mindset compared to their internet entrepreneurial behavior using the independent sample t-test formula with a significance level of 0.050 . The results of the analysis can be seen in Table 3, as follows:

Table 3. Summary of Results Independent Sample t-test

\begin{tabular}{lccccr}
\hline \multicolumn{1}{c}{ Kelompok } & Mean & SD & t-test & t-table & Sig. \\
\hline Fixed & 73.71 & 13.240 & 7.349 & 1.655 & 0.000 \\
Mindset & & & & & \\
$\mathrm{N}=69$ & & & & \\
Growth & 86,82 & 8.166 & $\begin{array}{l}\text { Hyphotesis } \\
\text { Accepted }\end{array}$ & & \\
Mindset & & & Act & \\
$\mathrm{N}=79$ & & & & & \\
\hline
\end{tabular}

Sumber: Data Olahan SPSS V.26

Based on the results of the analysis conducted to determine whether there are differences in internet entrepreneurial behavior in students with a fixed mindset and students with growth mindset, the price of t-count> t-table with $\mathrm{df}=146(7,349>1,655)$ means that there are differences in average results which means that between the two groups of students and the growth mindset group has a higher average score. Mc.Mullen and Kier (2016) state that entrepreneurial mind is the ability to identify and take advantage of opportunities without regard to the resources that are currently under their control. Entrepreneurial mindset changes the status of individuals into entrepreneurs. Therefore an individual becomes an entrepreneur thanks to the state of his mind that allows him to analyze the world and the opportunities and possibilities it offers (Reed and Stoltz, 2011).

\section{Correlation between Mindset and Internet Entrepreneurial Behavior}

The next test is testing to find out whether there is a relationship between student mindset with internet entrepreneurial behavior which is done using the pearson correlation product moment formula. The results of the analysis that have been carried out can be seen in the following Table 4:

\section{Table 4. Summary of Correlation Analysis Results}

\begin{tabular}{cccc}
\hline $\mathrm{N}$ & $\mathrm{r}$-test & interval r & Sig. \\
\hline 148 & 0.452 & $0.400-0.599$ & 0.000 \\
\hline & & \multicolumn{3}{c}{ Sumber: Data Olahan SPSS V.26 }
\end{tabular}

The results of the analysis using the Pearson correlation product moment formula that has been obtained obtained a $r$ count of 0.452 , this score is in the range of scores of $0.400-0.599$ with the interpretation that the student mindset has a positive and meaningful relationship with internet entrepreneurial behavior conducted by the University of Putra Indonesia students "YPTK "Padang and accepted at the 95\% significance level. This means having a very strong connection that mindset greatly influences student internet entrepreneurship behavior.

Based on the results of correlation analysis that has been done it is known that the correlation is at r-count 0.452 , this score has a contribution price of $20.4 \%$ which means that the mindset influences student internet entrepreneurial behavior by $20.4 \%$ which means that $79.6 \%$ is influenced by other factors. Entrepreneurial mind set is an entrepreneurial mindset about analyzing the world, its opportunities and possibilities, as well as understanding how an individual can contribute to the development and progress of the economic and social system and ultimately the conversion of ideas into action to achieve goals. Davis et al., (2016) states that entrepreneurial mind sets are a constellation of motives, skills, and thought processes that distinguish entrepreneurs from non-entrepreneurs. All definitions presented by various authors emphasize that the entrepreneurial mindset is closely related to thoughts, views and beliefs.

The research procedures carried out in this study can be illustrated in the following picture 1: 


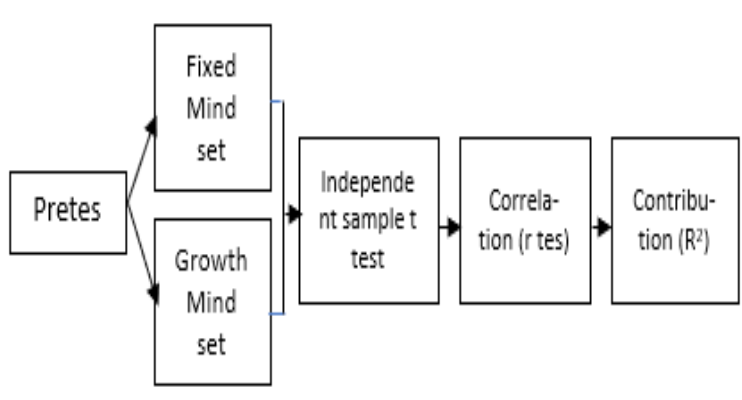

Picture 1. Mindset Framework

Sumber: Data Olahan SPSS V.26

The Thinking Flow Framework above illustrates that the pretest consists of a fixed mindset and growth mindset which is tested by independent sample t-test followed by correlation (r-test) and contribution (R2). This means a separate test between the personal mindset of the internet entrepreneurial behavior of students especially the Putra Indonesia University "YPTK" Padang. Likewise, the correlation (the relationship between personal mindset on entrepreneurial behavior is very strong which is shown from the processed data that has been done. Furthermore, the two variables contribute to each other which is well shown from the results obtained by $20.4 \%$.

\section{CONCLUSION}

The research conducted concluded that from 148 students who were sampled from the student population of Putra Indonesia University "YPTK" Padang based on the results of the personal mind set test, it was found that there were 69 students with fixed mindset and 79 students with growth mindset. After being grouped by students, then testing the mindset content states that the fixed mindset group has positive content that is lower than the growth mindset group. Hypothesis testing results to find out whether there are differences in internet entrepreneurial behavior in the two groups of students with different mind sets stated that the different test hypotheses were accepted at a significance level of $95 \%$ and the group with growt mind set had an average internet entrepreneurial behavior higher than the group of students with fixed mindset . Correlation testing is to test whether there is a relationship between mindset and internet entrepreneurial behavior with a score of $r$ which is in the range of positive correlation interpretation which is quite strong between the two variables, while the percentage of mindset contribution to internet entrepreneurial behavior shown by students is $20.4 \%$ and the rest is influenced by other factors not examined. The results of this study prove that the theory put forward by Dweck (2006) one's mindset will affect attitudes, talents and intelligence and character, growth mindset(growth) mindset is important in determining the progress and development of one's potential. It is proven that students with growth mind sets have the behavior to act in higher internet entrepreneurial activities. This student has positive behavior in developing basic quality beliefs in himself that can be developed through effort. The results of the study recommend that to increase the ability and interest of students in entrepreneurship must start from the approach to the right mindset about entrepreneurship. Mindset is beliefs that can affect a person's behavior, including entrepreneurial activities.

\section{REFERENCES}

Baron, R.A. (2014). Cognitive foundations of Entrepreneurship. In Essentials of Entrepreneurship. Evidence and Practice (1st ed., pp. 3-58). Cheltenham: Edward Elgar

Benny, L. (2014). WhoWants To Be an Entrepreneurs Pegawai Juga Bisa Jadi Pengusaha. Jakarta: PT. ELex Media Komputindo. Kompas Gramedia.

Chrisantiana, T.G. \& Sembiring, T. (2017). Pengaruh Growth dan Fixed Mindset terhadap Grit pada Mahasiswa Fakultas Psikologi Universitas " $\mathrm{X}$ " Bandung. Jurnal Humanitas, 1 (2), 354-362,

Danim, S. (2002), Metode Penelitian untuk Ilmu-ilmu Perilaku. Jakarta: Bumi Aksara.

Davis, H., Hall, A. \& Mayer, I.S. (2016). Developing a new measure of entrepreneurial mindset: reliability, validity, and implications for practitioners. Consulting Psychology Journal: Practice and Research, 68, (1), 21-48.

Duckworth, A. (2007). Grit: Perseverance and Passion for Long-Term Goals. Journal Of Personality \& Social Psychology. Volume 92, (6), 1087-1095.

Duckworth, A. (2016). Grit: The Power of Passion and Perseverance. Scribner.

Dweck, C.S. (2006). Mindset: The New Psychology of Success 1st edition. New York: The Random House Publishing Group.

Dweck, C.S. (2015). Revisits the 'Growth Mindset'. Education Week Friedenberg, Lisa. (1955). Psychological Testing: Design, Analysis, and Use. Massachusetts: Allyn\& Bacon.

Gerald, V.P. \& F.Pfaff, J (2007). Internet Entrepreneurship and Economic Growth. Journal of International Technology and Information Management. 16, (3), Article 3, 34-44.

Gollwitzer, P.M., Heckhausen, H. \& Steller, B. (1990). Deliberative and Implemental Mind-Sets: Cognitive Tuning Toward Congruous Thoughts and Information. Journal of Personality and Social Psychology, 59, (6), 1119-1127. 
Hindle, K. \& Moroz, P. (2010). Indigenous entrepreneurship as a research field: developing a definitional framework from the emerging canon. International Entrepreneurship and Management Journal, 6, (4), 357-385.

Hochanadel, \& Finamore. (2015). Fixed And Growth Mindset In Education And How Grit Helps Students Persist In The Face Of Adversity. Journal of International Education Research-First Quarter. 11 (1), 871-885.

Ireland, R.D., Hitt, M.A., \& Sirmon, D.G. (2003). A model of strategic enterpreneurship: The construct and itsdimensions. Journal of Management, 29, (6), 963-989.

Kollmann, T. (2006). What is eentrepreneurship? Fundamentals of company founding in the net economy. International Journal of Technology Management, 33, (4), 322-340.

Krisianto, A. (2014). Internet untukPemula: Panduan Menggunakan Internet secaraProduktif. Jakarta: PT. Elex Media Komputindo.

Lung, T.L. \& Liang, S.K. (2016). Road To Initial Public Offerings (Ipo): A Case Of Internet Entrepreneur In Taiwan. International Journal of Science Research And Technology. 2, (3), 9-14.

Mathisen, J.E., \& Arnulf, J.K. (2013). Competing mindsets in entrepreneurship: The cost of doubt. International Journal of Management Education, 11, (3), 132-141.

Matlay H. \& Martin, L.M. (2009), Collaborative and competitive strategies in virtual teams of e-entrepreneurs: a pan- European perspective, Australasian Journal of Information Systems. 16, (1), 99-115

McMullen, J.S., \& Kier, A.S. (2016). Trapped by the entrepreneurial mindset: Opportunity seeking and escalation of commitment in the Mount Everest disaster. Journal of Business Venturing, 31, (6), 663-686.

McMullen, J.S. \& Kier, A.S. (2016). Trapped by the entrepreneurial mindset: Opportunity seeking and escalation of commitment in the Mount Everest disaster. Journal of Business Venturing, 31, (6), 663-686.
Millman, W.C. Wong, Z.L. \& Matlay, H. (2009). Educating students for e-entrepreneurship in the UK, the USA and China. Industry and Higher Education, 23, (3), 243-252.

Muharika D, \& Mulyati, SR. (2019). Wirausaha Internet. Padang: CV. Muharika RumahI lmiah.

Naumann, C. (2017). Entrepreneurial Mindset: A Synthetic Literature Review. Entrepreneurial Business and Economic Review, 5, (3), 149-172

Pourhossein, M \& Omran, S.K.. (2014). The Role of E-Entrepreneurship In The Net Economy of Developed And Developing Countries. Kuwait Chapter of Arabian Journal of Business and Management Review, 3 (11a), 451-662.

Reed, J. \& Stoltz, P. G. (2011). Put your mindset to work. London: Penguin UK.

Romer, P.M. (1994). The origins of endogenous growth. Journal of Economic Perspectives, 8, (1), 3-22.

Schildt, H. (2012). The Field of Entrepreneurship: A Bibliometric Assessment. Journal Administrative Science Quarterl. 3, (3), 429-451.

Shepherd, D., Mosakowski, E., \&Earley, P.C. (2010). A situated metacognitive model of the entrepreneurial mindset. Journal of Business Venturing, 25, (2), 217-229.

Stevens, N. (2010). Online Trust \& Internet Entrepreneurs: A Kantian Approach. Scholarly Commons Wharton Research Scholars Wharton School.

Taylor, T. (2017). 10 Tips for the Beginning Internet Entrepreneur.http://www.htmlgoodies. com/html5/slideshows / 10 -tips-forthe-beginning-internet-entrepreneur. html\#fbid=YGdmTOoEeAU(diakses pada Hari Jum'at, Tanggal 20 Desember 2019 Jam 20.51 WIB)

Welter, F. \& Lasch, F. (2008). Entrepreneurship research in Europe: Taking stock and looking forward. Journal Entrepreneurship Theory and Practice, $32,(2), 241-248$. 